\title{
APPLICATION OF BUCCAL FAT PAD AS ADJUNCT FLAP FOR LATERAL DEFECT CLOSURE IN PALATOPLASTY
}

\author{
Nurwahida ${ }^{1}$, Connie Christina ${ }^{2}, \&$ Malvin Jonathan ${ }^{3 *}$ \\ 1. Oral Surgeon of Faculty Dentistry Hasanuddin University, Indonesia \\ 2. General Practitioner of Labuha District Hospital, North Moluccas, Indonesia \\ 3. General Practitioner of Faculty Medicine, Universitas Kristen Krida Wacana, Jakarta, Indonesia
}

\begin{abstract}
Summary: Cleft lip and palate are the most widely recognized craniofacial congenital malformation. The buccal fat pad (BFP) can be utilized to close lateral fistulas at the time of palatoplasty due to its rich blood supply and simple accessibility. The aim is to report on the use of BFP as a pedicled flap in cleft palate surgery and to discuss promising results for this reconstructive concept. The case subject was a five-year-old male born with cleft lip and palate; the cleft lip was operated on 4 months old. The patient was operated on using Bardach's two flap palatoplasty techniques, and for the closure of the lateral lining defect, the BFP was used as a pedicled flap.

After the surgery, no abnormality was found, including infection, graft loss, palatal fistulas, or cheek depression. All wounds were fully epithelialized. In palatoplasty, BFP is a safe and reliable method with a fast healing benefit. Keywords: Buccal Fat Pad; Cleft Palate Repair; Palatoplasty; Palatal Fistulas.
\end{abstract}

\section{ABSTRAK}

Ringkasan: Celah bibir dan langit-langit merupakan kelainan kongenital kraniofasial yang paling dikenal luas. Bucal Fat Pad (BFP) dapat digunakan untuk menutup fistula lateral pada saat palatoplasti karena kaya akan suplai darah dan aksesibilitas yang sederhana. Tujuan dari tulisan ini adalah untuk melaporkan penggunaan BFP sebagai graft pedicel dalam operasi celah langit-langit dan untuk mendiskusikan hasil dari konsep bedah rekonstruktif ini. Pasien adalah laki-laki berumur lima tahun yang lahir dengan sumbing bibir dan langit-langit mulut dan untuk bibir sumbing telah dioprasi saat berumur 4 bulan. Pasien dioperasi untuk dua flap palatoplasti Bardach dan untuk menutup defek lateral lapisan dalam. Perbaikan celah langit-langit menggunakan BFP sebagai graft pedicel.

Setelah operasi tidak ditemukan kelainan yang meliputi infeksi, kehilangan graft, fistula palatal, atau cekungan pipi dan terepitelisasi penuh. Dalam kasus palatoplasti, penggunaan BFP adalah metode yang aman dan andal dengan manfaat penyembuhan yang cepat.

Kata kunci: Bucal Fat Pad; Perbaikan Celah Langit-Langit; Palatoplasti; Fistula Palatal.

Conflicts of Interest Statement:

The author(s) listed in this manuscript declare the absence of any conflict of interest on the subject matter or materials discussed. 


\section{INTRODUCTION}

Cleft lip and palate are the most widely recognized craniofacial congenital disorder. Numerous patients, particularly with a wide cleft palate, may create a lateral fistula due to surgery complications. The buccal fat pad (BFP) is an encapsulated mass from a particular fat tissue with different volumes throughout life. BFP has been used in various medical procedures such as cleft surgery as a valuable tissue flap due to its rich blood supply and simple accessibility. It also can be utilized for the closure of lateral fistulas for palatoplasty. ${ }^{1,2}$

This article aims to report on using BFP as an adjunct flap in cleft palate surgery and publicize promising results for this reconstructive surgical concept.

\section{CASE REPORT}

Five years old male child patient admitted to Labuha Hospital as a part of social

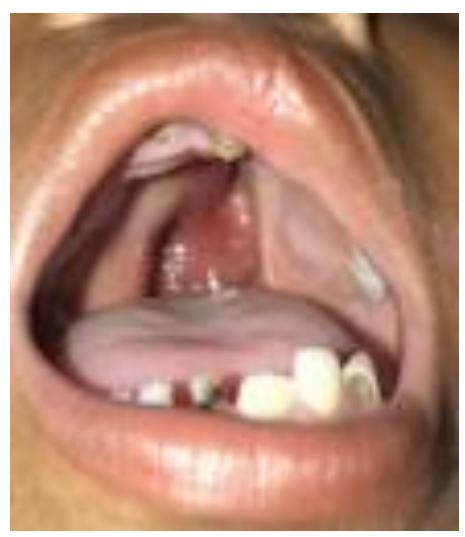

service on National Health Day. The patient presented nasal regurgitation and abnormal speech. Before and during the pregnancy, the mother of the patient took an anticonvulsant drug. It turns out the patient was born with a cleft lip and palate. Previously the patient was operated on for cleft lip at 4 months old. The family knew no other past familial history of the patient. The general assessment of the patient shows the normal result for all parameters.

Meanwhile, we found a cleft palate with the size of approximately $3 \times 3 \times 1,5 \mathrm{~cm}$ on local assessment (Figures 1). The baby received routine investigations for general anesthesia application such as CBC, LFT, RFT, and chest X-ray. The result indicated a normal condition. Finally, the patient was examined to find out any other congenital disorders, but none were identified.

In the pre-operative phase, the patient was given IV fluids and IV antibiotics. The patient was operated on under general anesthesia for palate closure using Bardach's two-flap

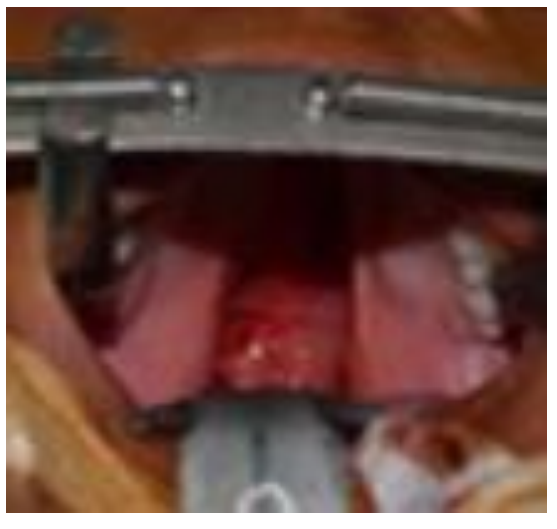

Figures 1. (Left and Right). Pre-operative intraoral photograph of patient showing complete cleft palate

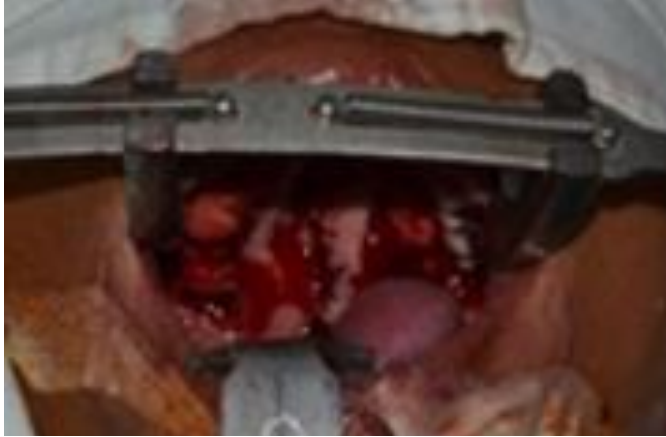

Figure 2. Immediate post-op photo of the patient showing Bardach's two flap palatoplasty with BFP laterally sutured

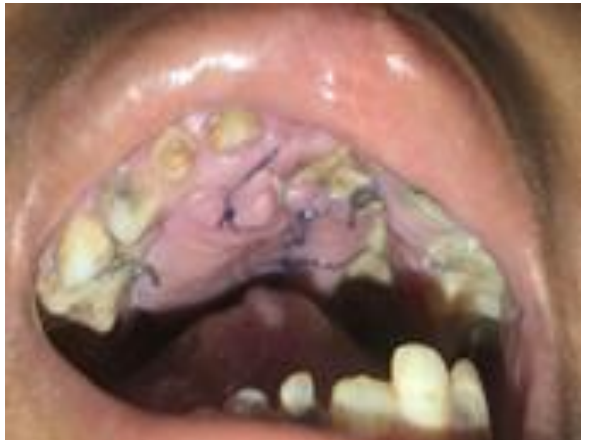

Figure 3. Post-op clinical photo of the patient after eight days showing well epithelialized BFP and satisfactory healing 
palatoplasty. To close the lining lateral defect, We used the BFP as the adjunct flap (Figure 2). The BFP was taken using blunt dissection and placed towards the lateral palatal defect's area, sutured with light pressure on the flap's edge, and left open for the epithelialization process. Interrupted techniques using 4.0 absorbable multifilament thread were performed for suturing. The operation lasted 3 hours, longer than a reconstruction without a BFP. After the surgery, the patient was maintained for oral hygiene every day to avoid infection by rinsing and cleaning the intraoral cavity and was given antibiotics for a week.

The patient does not show any perioperative complications related to the buccal fat pad. The recipient area is fully epithelialized. Infection, loss of graft, palatal fistulas, or cheek depression were not found. (Figure 3)

\section{DISCUSSION}

Due to the relative paucity of tissues, surgical repair of palatal clefts can be challenging. Palatal fistulas are often caused by tension due to loss of tissue or tissue mobility, single-layer repair, and poor wound healing. However, BFP has been used as a helpful flap material due to its rich blood supply and simple accessibility in various medical procedures. The utilization of adjunctive BFP may answer these issues by improving accessibility of tissues for repairing, and it may likewise help wound healing be significantly quicker due to another layer of tissue structure and its vascularity characteristics. Clinically for this case, in particular, the oral surface initially showed yellowish-white fat, but 3 days after the surgery, it gradually became red within a week. By the time, healthy-looking oral mucosa covered up the graft. The success, in this case, is similar to the findings of other authors, who used BFP in the repair of various intraoral defects. A clinical study conducted by Zhang et al. ${ }^{3}$ observed the impact on maxillary growth in cleft palate patients; they found that patients who were un $\neg$ dergoing reparative surgery with buccal fat pads filling in the bilateral raw bony surfaces had a decreased area of palate scar tissue and a reduced effect of the post-ope $\neg$ rative scar on maxillary growth.

The BFP has grown in recognition as an alternative to conventional modes of maxillary defect reconstruction; however, its use as an adjunct in palatal cleft repair is still in its developmental stages. Reports of its use in palatal cleft repairs in Africa are certainly scarce in the literature. ${ }^{4,5}$ It is a reliable flap with good vascularity, easy to mobilize, simple to harvest, and low complication rates. ${ }^{6,7}$

\section{SUMMARY}

The buccal fat pad is a safe and reliable method with immediate healing benefits in treating a cleft palate's lateral defect.

\section{ACKNOWLEDGEMENT}

Authors acknowledge all of the staff of social service: cleft lip and palate in Labuha Hospital, North Maluku, Indonesia, for helping authors to collect data of medical record.

\section{Correspondence regarding this article should be addressed to: \\ Malvin Jonathan. Faculty of Medicine, Universitas Kristen Krida Wacana, Jakarta, 12860, Indonesia. \\ E-Mail: malvinjonathand@gmail.com}

\section{REFERENCES}

1. Ladani PS, Sailer HF. Application of buccal fat pad for the lining of the lateral defect in cleft palate repair and literature review. Journal Cleft Lip Palate-Craniofacial Anomali. 2016;3:63-6

2. Ruslan M, Hajrah-Yusuf AS, Tajrin A, Lo LJ, Forouzanfar T. Utilization of pedicled buccal fat pads for coverage of the lateral relaxing wound: A review of literature and a case series of 15 patients. Journal Clinical Experimental Dentistry. 2018;10(5):e502-6.

3. Zhang M, Zhang X, Zheng C. Application of buccal fat pads in pack palate relaxing incisions on maxillary growth: a clinical study. International Journal Clinical Experimental Medicine. 2015;8:2689-92.

4. Bettoni CH, Melo MFS, Zaosa LND. Use of the buccal fat pad as free graft for closure of oronasal fistula in a cleft palate patient. Journal Craniofacial Surgery. 2015;26:e14-6

5. Pappachan, Biju et al. Application of bilateral pedicled buccal fat pad in wide primary cleft palate. British Journal of Oral and Maxillofacial Surgery.2008;46: 310 - 312 
6. Adeyemo $\mathrm{WL}$, Ogunlewe $\mathrm{MO}$, Ladeinde $\mathrm{AL}$, James O. Closure of oro-antral fistula with pedicled buccal fat pad: a case report and review of literature. Afr J Oral Health. 2004;1:42-46.
7. Stajčić Z. The buccal fat pad in the closure of oro-antral communications: a study of 56 cases. J Cranio-Maxillofac Surg. 1992;20:193197. 